\title{
Widening the area of a Baikal endemic Leymus secalinus (Georgi) Tzvelev. (Poaceae) northward to the Aldan River basin (Yakutia) based on the molecular genetic study results
}

\author{
Natalia Badmaeva $^{1 *}$, Dolgor Tubanova ${ }^{1}$, and Evgenia Bukharova $^{2}$ \\ ${ }^{1}$ Institute of General and Experimental Biology of the Siberian Branch of the RAS, Ulan-Ude, Russia \\ ${ }^{2}$ Federal State Establishment United Administration of Barguzinsky State Nature Biosphere Reserve \\ and Zabaikalsky National Park ("Zapovednoe Podlemorye"), Ust-Bargizin, Russia
}

\begin{abstract}
The paper presents the results of studying the taxonomic relationships of Leymus secalinus (Georgi) Tzvelev. and L. littoralis (Griseb.) Peschkova in different geographical sites based on a comparison of ITS1-5.8S-ITS2 sequences of nuclear rDNA and cpDNA matK. Molecular genetic research of these species allowed us to expand the area of L. secalinus to the Aldan River basin (Yakutia).
\end{abstract}

\section{Introduction}

The genus Leymus (Hochst.) is polymorphic one, that's why there are many unclear and controversial points in the taxonomy of the genus some species. The problematic taxon is Leymus secalinus (George) Tsvel. First L. secalinus. II was described by I.I.Georgi as Triticum secalinum Georgi on the basis of the dolinneevskyi description and species images on Steller's gatherings from the sandy shores of Lake Baikal and the island Olkhon, which were published by I.G. Gmelin, in «Flora Sibirica», Table. 25 [1]. A year later Pallas called this plant at the same description and Gmelin`s image - Triticum littorale Pall. The type $T$. littorale Pall. is still the same drawing of I.G. Gmelin from «Flora Sibirica», Table 25 [1]. E.G. Bobrov [2] notes that the name given by I.I. Georgi is a priority. Here E.G. Bobrov indicates that Ledebour in 1853 in «Flora Rossica» mentions both named binominala and that plant which was discussed by Steller, Gmelin, Georgi and Pallas, and it is qualified as a special variety of Elymus dasystachys $\beta$ littoralis Griseb. The named species was established in 1829 by Triniusom in S.F. Ledebour's «Flora Altaica» from salt licks Chui.

G.A. Peshkova [3], studying samples of L. secalinus s. str. at classical site (E. littoralis) in Posolsk village vicinity on the Lake Baikal southeastern shore, has singled out $L$. littoralis (Griseb.) Peschkova from L. secalinus (George).

\section{Materials and methods}

\footnotetext{
${ }^{*}$ Corresponding author: badmayevan@mail.ru
} 
The material for molecular genetic analysis was 38 samples of 5 species of the genus Leymus collected by the authors in sites of species natural growth during expeditions to various regions of Russia (Altai, Tuva, Irkutsk Region, Buryatia, Yakutia: Aldan, Zhatai, Yakutsk), Mongolia, China, and Kazakhstan in 2008-2018 (Fig. 1.). Herbarium samples are stored in UUH herbarium. DNA was isolated from samples dried in silica gel using NucleoSpin Plant II Kit (Macherey-Nagel, Germany) according to the standard protocol.

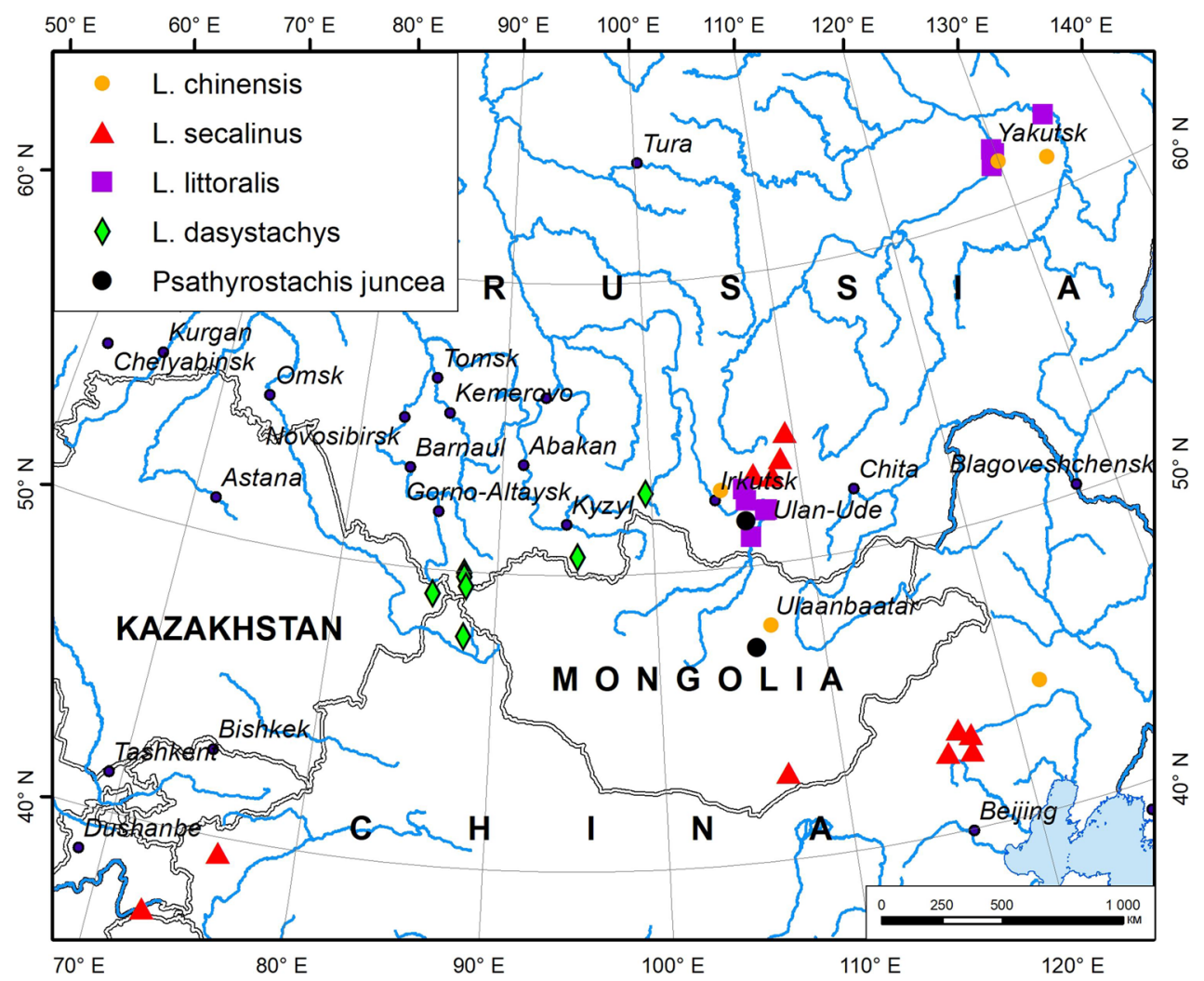

Fig. 1. Map of keysites to collect the genus Leymus species for molecular genetic analysis

Polymerase chain reaction (PCR) was carried on in a BIO-RAD t100tm thermal cycler (BIO-RAD, USA). The volume, reaction mixture composition, and amplification conditions were described in detail earlier [4]. The rDNA ITS1-5.8S-ITS2 section was amplified and sequenced using primers: ITS1 (F) TCCGTAGGTGAACCTGCGG, ITS-B (R) GATATGCTTAAACTCAGCGG. The cpDNA matK region was amplified with two pairs of primers: $($ matK $\mathrm{W}$ (F) TACCCTATCCTATCCAT, matK 9(R) TACGAGCTAAAGTTCTAGC; matK S5-1(F) ACCCTGTTCTGACCATATTG, matK 1210(R) GTAGTTGAGAAAGAATCGC. DNA sequencing was performed using the Sanger method in Co. "Syntol" (Moscow).

To create the tree, the analysis included samples of the closely related species $L$. dasystachys (Trin) Pilger, as well as the species often grown in the same community together with L. secalinus and L. littoralis - L. chinensis (Trin.) Tzvel. The phylogenetic tree was done with Winclada software [5], using Nona [6] based on the combined sequences of rDNA ITS1-5.8S-ITS2 and cpDNA matK regions (Fig. 1), with a length of 1,985 nucleotide pairs for a single sample. As an outgroup, sequences of 2 samples of the species Psathyrostachys junsea (Buryatia, Selenga District; Mongolia) were taken. 


\section{Results and discussion}

Earlier, the independence of the species L. secalinus (Georgi) Tzvel. and L. littoralis (Griseb.) Peschkova [7] has been confirmed based on studying rDNA ITS1-5,8S-ITS2 sequences. L. littoralis from Buryatia and L. secalinus from Mongolia and China form a separate clade, which indicates their unity.

According to G.A. Peshkova [3], L. secalinus distribution is limited to the northern shore of Lake Baikal and Olkhon Island, and the species is a Baikalian endemic one; southward - on Lake Baikal shores and in the island steppes of Pribaikalia, Transbaikalia, Yakutia, and northern Mongolia - another species L. littoralis (Griseb.) Peschkova grows [8]. Our research of 4 L. littoralis samples in Yakutia (Fig. 2, a) has shown that all studied samples belong to $L$. secalinus (Fig. 2, b) forming a single clade. As well, research of $L$. littoralis samples in the classical habitat (Posolsk village vicinity) has presented that both $L$. littoralis and L. secalinus grow there together. That is, samples collected from the same habitat have been included in different clades (Fig. 2, c).

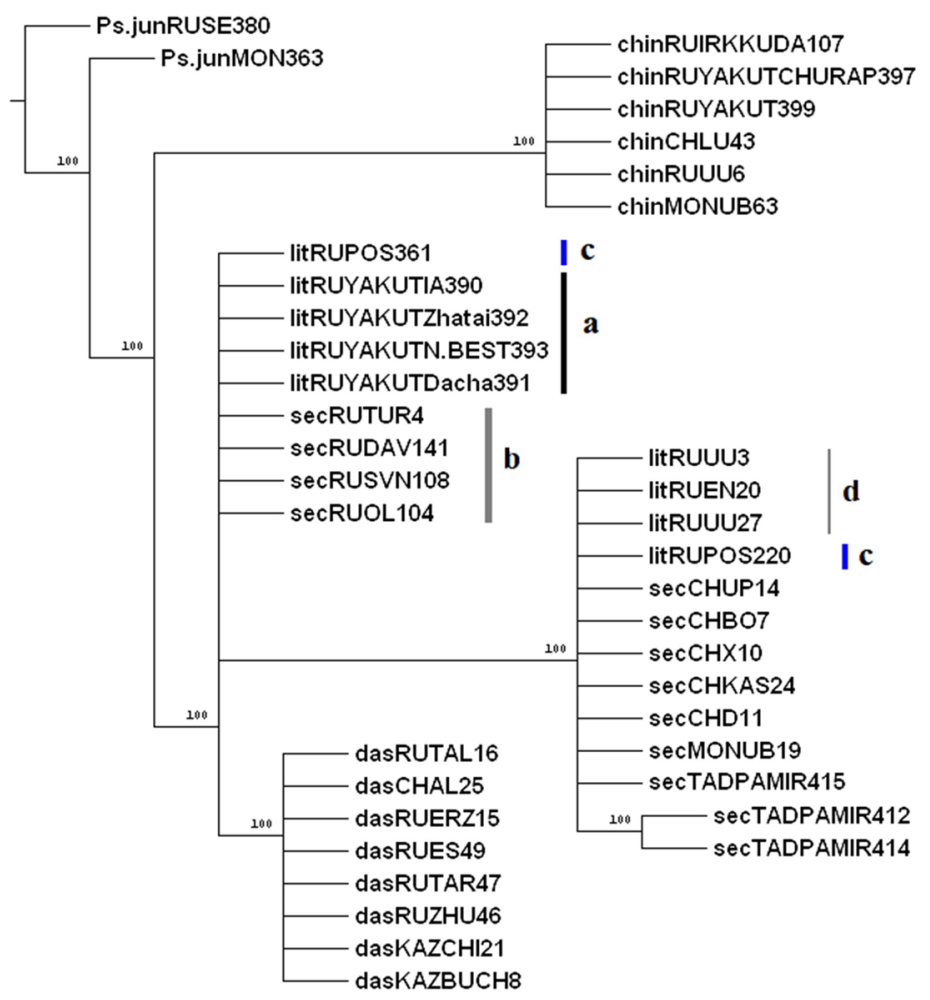

Fig. 2. Combined phylogenetic tree of 5 species of the genus Leymus based on rDNA ITS1-5,8S-ITS2 and cpDNA matK region sequences

In addition, morphological studies of Yakutian samples have been done and revealed that they are morphologically close to L. secalinus from Lake Baikal shores, rather than to $L$. littoralis (Fig. 3.) Yakutian samples, as well as in L. secalinus, have awns of the lower squama (LS) of the lowest flower of a spikelet, which do not exceed $2.5 \mathrm{~mm}$, whereas awns of $L$. littoralis are much longer and not less than 3.5-3.8 mm. LS indumentum can vary in a wide range. It should be marked that both Yakutian samples of L. littoralis and Baikalian $L$. secalinus samples have waxy coating on LSs. 
Based on studying sequences of rDNA ITS1-5,8S-ITS2 and cpDNA matK of $4 \mathrm{~L}$. littoralis samples in Yakutia, it has been revealed that all studied samples belong to $L$. secalinus.

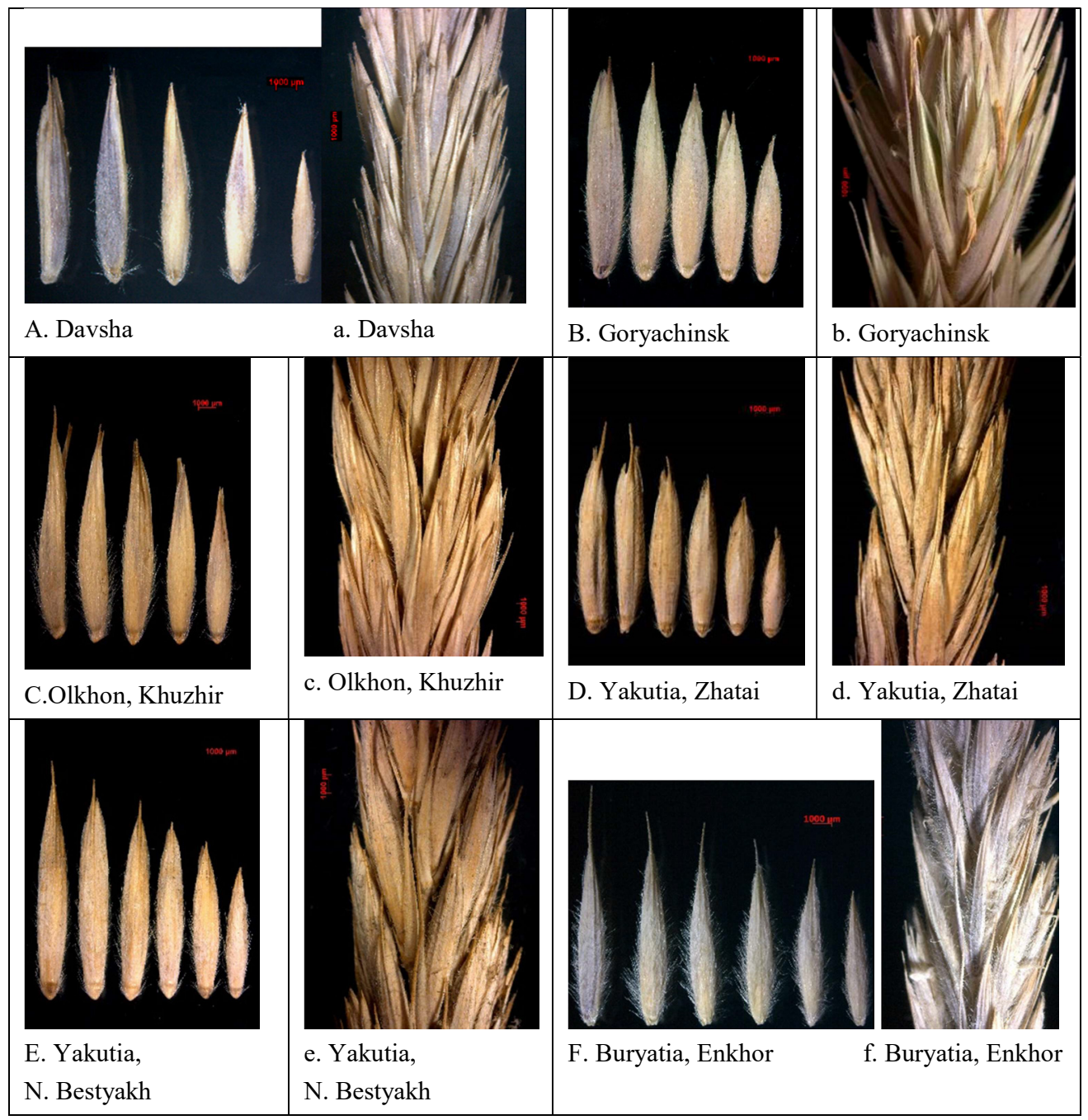

Fig. 3. L. secalinus (A, B, C); L. littoralis (D, E, F). A, B, C, D, D, E-flowers of a spikelet; a, b, c, d, $\mathrm{e}, \mathrm{f}-\mathrm{a}$ spikelet middle part.

Based on studying sequences of rDNA ITS1-5,8S-ITS2 and cpDNA matK of $4 \mathrm{~L}$. littoralis samples in Yakutia, it has been revealed that all studied samples belong to $L$. secalinus. Therefore, the species area is wider than thought previously. As well, research of L. littoralis samples from the classical habitat (Posolsk village vicinity) has shown that both L. littoralis and L. secalinus grow there.

The work was carried out by the research issue (State task AAAAA 17-117011810036-3), as well as the project RFBR-Buryatia № 18-45-030026. 
1. I.G. Gmelin. Flora sidirica. 1. 247. (Petropoli, 1747).

2. E.G. Bobrov. Botanic materials of a herbarium in the Botanic institute of V.L. Komarov of the Academy of Sciences of the USSR. 20: 1-22. (Leningrad, 1960) (In Russian)

3. G. A. Peshkova. News of High Pl. Syst. 24, 21-26 (1987) (In Russian)

4. N. K. Badmaeva, D. Ya. Tubanova, A. V. Agafonov, Pl. Life of Asian Russia 1, 82-90 (2018) (In Russian)

5. K. C Nixon. Winclada (BETA) ver. 0.9.9. available at http://www.cladistics.com/about_winc.html (1999)

6. P. A Goloboff. NONA: software and documentation. (Tucuman. 1994).

7. N. K. Badmaeva, D. Ya. Tubanova, H. Liu, A. V. Agafonov. Relationships among Leymus secalinus (Poaceae) and closely related species based on sequence analysis of the nuclear ribosomal DNA internal transcribed spacer region (ITS) in Proceeding of the $7^{\text {th }}$ International Triticeae Symposium, Chengdu, China, June 9-13 (2013)

8. G. A. Peshkova. Siberian Flora 2: 41-53. (1990) (In Russian) 